DOI: 10.35757/RPN.2011.19.07

Adam Jarosz

\title{
ROLA UNII EUROPEJSKIEJ W SPORZE O GAZOCIĄG PÓŁNOCNY. KOMENTARZE W PRASIE POLSKIEJ I NIEMIECKIEJ
}

\begin{abstract}
Wstęp
Realizacja projektu gazociągu północnego rozpoczęła się w roku 2005. W tym celu stworzono spółkę North European Gas Pipeline Company, której nazwę zmieniono potem na Nord Stream. Początkowo udziałowcami zostały podmioty: rosyjski Gazprom ${ }^{1}$ (51\%), niemieckie Wintershall Holding $\mathrm{AG}^{2}(24,5 \%)$ i E.ON Ruhrgas $\mathrm{AG}^{3}(24,5 \%)$. W późniejszym etapie realizacji inwestycji dołączył holenderski N.V. Nederlandse Gasunie ${ }^{4}$ (9\%) i francuski GDF Suez (9\%) dzięki odkupieniu części udziałów od niemieckich spółek, które pozostały w posiadaniu po 15,5\% udziałów. Przewodniczącym rady nadzorczej spółki został były niemiecki kanclerz Gerhard Schröder, a na siedzibę wybrano szwajcarskie miasto Zug. Rurociąg miał połączyć Rosję z Niemcami \footnotetext{
2010].

2 Niemiecka spółka zajmująca się wydobyciem gazu ziemnego i ropy naftowej, część grupy BASF, patrz: www.wintershall.com [dostęp: 14 lipca 2010].

3 Największa niemiecka spółka zajmująca się handlem gazem, patrz: www.eonruhrgas.com [dostęp: 14 lipca 2010].

4 Holenderska spółka zajmująca się transportem gazu, patrz: www.gasunie.nl [dostęp: 14 lipca 2010].
}

1 Największy rosyjski koncern gazowy, patrz: www.gazprom.com [dostęp: 14 lipca
\end{abstract}


przez Morze Bałtyckie, z pominięciem państw trzecich. Jego przebieg planowano po dnie morskim od Wyborga do Greifswaldu, a łączna długość miała wynosić $1224 \mathrm{~km}$. Docelowo rurociąg miał osiągnąć przepustowość 55 miliardów ton gazu rocznie 5 .

Gazociąg północny okazał się projektem kontrowersyjnym od momentu, gdy zaczęto go realizować. Główną rolę odegrały przy tym media, które nagłośniły problem, a w szczególności obawy, jakie wywołała ta inwestycja w Polsce i innych krajach nadbałtyckich.

Bardzo ważną rolę w sprawie gazociągu północnego odegrała Unia Europejska. Stało się tak, ponieważ praktycznie wszystkie państwa zaangażowane w spór były jej członkami, w związku z czym odwoływały się do jej instytucji, próbując blokować inwestycję. Rola UE miała też drugie dno. Budowniczowie rury podkreślali, że jest to projekt europejski, który ma służyć wszystkim państwom członkowskim.

Artykuł ten ma na celu ukazanie debaty prasowej, która odbyła się w Polsce i w Niemczech oraz przedstawienie, co i w jakim kontekście pisano o roli Unii Europejskiej w sporze o gazociąg północny, a nie dokumentowanie i opisywanie faktów związanych z realizacją tego projektu ${ }^{6}$.

Bazą źródłową artykułu są artykuły, analizy, komentarze i notatki z sześciu gazet codziennych i czasopism - trzech z Polski i trzech z Niemiec. Wybrano po dwie gazety codzienne i po jednym kolorowym tygodniku. Zamysłem autora było przy tym znalezienie najbardziej opiniotwórczych periodyków. Z prasy polskiej wykorzystano: "Gazetę Wyborczą", „Rzeczpospolitą" i „Wprost”, z niemieckiej: „Frankfurter Allgemeine Zeitung” („FAZ”), „Süddeutsche Zeitung” i „Der Spiegel”.

5 Patrz: www.nord-stream.com [dostęp: 14 lipca 2010].

6 Analizy naukowe dotyczące zagadnienia gazociągu północnego przeprowadzili m.in.: D. Bugajski: Gazociag pótnocny w świetle prawa morza i polityki battyckiej, „Stosunki Międzynarodowe" 2007, t. 36, nr 3-4; F. Kazin: Globalna strategia Gazpromu, a narodowe interesy Rosji, „Polski Przegląd Dyplomatyczny” 2006, nr 1 (29); R. Tarnogórski: Gazociag Pótnocny. Aspekty prawne, "Polski Przegląd Dyplomatyczny” 2006, nr 1(29); F. Umbach: Energiesicherheit im 21. Jh. Die verkannte Bedeutung der zukunftigen Versorgungssicherheit, w: Deutsche Energiepolitik, red. L. Kleinwächter, Potsdam 2007; K.O. Lang: Mit Sicherheit - Polens Energiepolitik zwischen europäischen Solidarität und russischen Abhängigkeit, „Polen Analysen“ 2006, nr 2; A. Jarosz: Gazociag pótnocny - inwestycja ekonomiczna czy polityczna? Komentarze w prasie polskiej i niemieckiej, "Historia i Polityka” 2009-2010, nr 2-3 (9-10). 
Wszystkie artykuły pochodzą z okresu pomiędzy październikiem 2005 roku a październikiem 2007 roku. O wyborze takiego przedziału czasowego zadecydował fakt, iż w Polsce sprawowała rządy partia Prawo i Sprawiedliwość. Liderzy tej partii znacznie zmienili i zaostrzyli ton polityki wobec Niemiec i Rosji, głównych konstruktorów gazociągu. W tym też czasie podjęto decyzję o jego budowie, co spowodowało, że debata była najgorętsza. Po zmianie rządu w Polsce $\mathrm{w}$ październiku 2007 roku temat gazociągu nie zniknął całkowicie z mediów, jednak sprawa ta przestała budzić już tak duże emocje, jak było to wcześniej.

\section{Rola Unii Europejskiej w sporze}

Pierwszą poruszoną w prasie w Polsce kwestią była rola UE w stosunkach handlowych z Gazpromem. Na łamach „Rzeczpospolitej” informowano o szczycie UE-Rosja, który odbył się w maju 2006 roku $\mathrm{w}$ rosyjskim Soczi. Przed tym wydarzeniem korespondentka gazety w Brukseli Anna Słojewska spekulowała: „przewodniczący Komisji Europejskiej Jose Barroso raczej nie zapyta prezydenta Władimira Putina o kontrowersyjny dla Polski gazociąg północny, bo Bruksela woli nie mieszać się w polsko-niemiecki spór". Dodawała, że Rosja to pewny dostawca, na którym można polegać jeszcze od czasów radzieckich. Sugerowała też, że „nowi członkowie irytują Moskwę”, przytaczając krytyczną wypowiedź rosyjskiego ambasadora przy UE Władimira Czyżowa. Litewski eurodeputowany Vytautas Landsbergis zaprzeczył zaś, twierdząc, iż „wpływ nowych państw UE na stosunki z Rosją jest pozytywny. Więcej szczerości i otwartości. [...] w najważniejszej dziś dziedzinie energii stare państwa członkowskie zaczynają myśleć bardziej trzeźwo"7 . Na szczycie dyskutowano o zwiększeniu dostępu firm europejskich do rosyjskiego rynku i złamaniu monopolu Gazpromu. Podniesiono też kwestię ratyfikacji przez Rosję Europejskiej Karty Energetycznej, która miała umożliwić otwarcie zarówno rynków europejskich dla Moskwy, jak i rosyjskich dla UE. Rosjanie byli temu przeciwni, czemu jasno dał wyraz Siergiej Jastrzębski, doradca prezydenta Putina ds.

\footnotetext{
7 A. Słojewska: Nowi członkowie irytują Moskwę, „Rzeczpospolita”, 23 maja 2006.
} 
UE: „Rosja nie jest członkiem Unii, u nas obowiązują inne reguły gry, które w obecnej chwili odpowiadają potrzebom naszej gospodarki". W załączonej do artykułu wypowiedzi zauważył on niechęć, z jaką patrzyły na jego kraj nowe państwa członkowskie. Zwrócił również uwagę na „różnice w podejściu do projektów realizowanych przez Rosję w Europie. Choćby gazociągu północnego. Unia Europejska popiera tę inicjatywę, słusznie zauważając, że jej głównym celem jest zwiększenie bezpieczeństwa energetycznego Europy". Dodał przy tym, że Rosja prowadzi politykę dwutorową - wobec UE jako całości i wobec poszczególnych państw członkowskich ${ }^{8}$ Tuż po spotkaniu Paweł Reszka na łamach tego samego pisma raportował o słowach Putina, wyrażających oczekiwanie na dopuszczenie Rosjan do europejskich rynków $\mathrm{w}$ zamian za otwarcie rosyjskiego sektora energetycznego. Zinterpretował on to jako „nie” dla wspomnianej karty energetycznej. Zauważył jednak, iż „podczas szczytu Władimir Putin znów reklamował gazociąg północny jako inwestycję mającą zwiększyć bezpieczeństwo energetyczne”, dodając, że „większość [...] członków UE nie widzi w rurze żadnego zagrożenia" ${ }^{9}$. O szczycie pisał też Andrzej Kublik na łamach „Gazety Wyborczej”, podnosząc kwestię roli Karty Energetycznej, która miała „znieść monopol Gazpromu na eksport gazu z Rosji i bariery dla zagranicznych inwestycji w rosyjską energetykę. [...] Chodzi też o zagwarantowanie zachodnim inwestorom, że będą mogli na własną rękę, poza monopolem państwa, budować rurociąi w Rosji i nie obawiać się, że kiedyś zostaną one znacjonalizowane". Rosja nie zamierzała się jednak na to zgodzić, ale chciałaby mieć możliwość uczestnictwa w rynkach europejskich, co - jak twierdził komentator - „groziłoby uzależnieniem Europy od firm, które kontrolują cały łańcuch od źródeł gazu po piecyk czy gniazdko". Zwrócił też uwagę na niepewność Rosji jako dostawcy, przytaczając wypowiedź szefa Komisji Europejskiej Jose Emanuela Barroso, według którego „surowce są nie tylko towarem, ale także narzędziem polityki"10.

8 P. Reszka: Gazprom nadal dzieli, „Rzeczpospolita”, 25 maja 2006.

9 P. Reszka: Putin nie ulega, „Rzeczpospolita”, 26 maja 2006.

${ }^{10}$ A. Kublik: Wtadimir Putin o ropie, gazie i cukierkach, "Gazeta Wyborcza”, 27-28 maja 2006. 
Szczyt w Soczi opisano także w "Süddeutsche Zeitung”, akcentując, podobnie jak $\mathrm{w}$ prasie polskiej naciski na podpisanie karty energetycznej przez Rosję. Także i tutaj zacytowany został Siergiej Jastrzębski, który dał do zrozumienia: „w karcie jest dużo dobrych punktów, ale niektóre ustalenia nam nie odpowiadają. Chcemy, żeby karta uwzględniała nie tylko interesy UE, ale także Rosji". Daniel Brössel odnotował także wypowiedź prezydenta Putina, który nazwał gazociąg północny „przykładem woli jego kraju, by zabezpieczyć bezpieczeństwo zaopatrzenia”, ponieważ celem Rosji jest polepszenie w ten sposób „jakości życia europejczyków" ${ }^{\prime 11}$. W komentarzu zamieszczonym w monachijskim dzienniku stwierdzono zaś, iż „właściwym było na szczycie UE-Rosja w Soczi mówić o energii. Błędem było jednak, dużo od niego oczekiwać". Szanse na podpisanie przez Rosję karty energetycznej były niewielkie, bowiem Kreml nie mógł zrezygnować z monopolu na gaz, ponieważ „pod rządami Władimira Putina Rosja uważa ropę naftową i gaz za środki

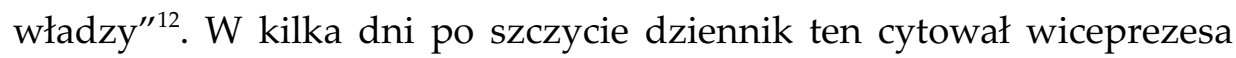
Gazpromu Aleksandra Miedwiediewa, który zarzucał UE, że przez żądania otwarcia rynku surowców mieszała się w sprawy firmy. Według Michaela Baumüllera, dziennikarza gazety zajmującego się gospodarka, rosyjski gigant opierał się przede wszystkim na kontraktach długoterminowych, które dla Gazpromu „są jak pismo święte”. Przedstawiciele UE tłumaczyli zamiar wejścia na rynek energetyczny w Rosji zapewnieniem bezpieczeństwa dużych koniecznych inwestycji w ów sektor w tym kraju. Rosjanie zaś już dokonywali wielu inwestycji, by wejść na rynki europejskie. Gazociąg północny był jedną z nich. Naciskali przy tym: „musi być zabezpieczone, że gaz z Niemiec będzie transportowany dalej [...] mniej więcej do Wielkiej Brytanii"13.

Na tym przykładzie widać, jak Rosjanie próbowali wykorzystywać swoją silną pozycję w relacjach z Unią Europejską. Podpisanie Europejskiej Karty Energetycznej mogłoby bowiem znacznie ograniczyć ich monopol na handel surowcami, a co za tym idzie, obniżyć znaczenie polityczne. Prasa polska i niemiecka zauważyły to i zgodnie odnotowa-

\footnotetext{
${ }^{11}$ D. Brössler: Entspannung im Energiestreit, „Süddeutsche Zeitung“, 26 maja 2006.

${ }^{12}$ Putins halbe Wahrheit, „Süddeutsche Zeitung“, 26 maja 2006.

${ }^{13}$ M. Bauchmüller: Gazprom rüffelt Brüssel, „Süddeutsche Zeitung“, 29 maja 2006.
} 
ły, pokazując przy tym także rolę gazociągu północnego jako jednego ze środków do wzmocnienia pozycji Rosjan na rynkach Europy.

O gazociągu północnym media informowały też przy okazji szczytu Unii Europejskiej w Brukseli w czerwcu 2006 roku. Jeszcze przed tym wydarzeniem w „Rzeczpospolitej” opisano sprzeciw Polski wobec możliwości finansowania inwestycji przez Brukselę. Ta chciała bowiem przyjąć wnioski o „pełnym poparciu UE dla projektów, których celem jest otwarcie nowych dróg dostaw energii", co mogłoby otwierać drogę do wsparcia finansowego dla rurociągu bałtyckiego z kasy wspólnoty ${ }^{14}$. Po szczycie w tym samym dzienniku pisano o przyjęciu zapisu mówiącego, że „wspólne pieniądze będą szły tylko na takie projekty energetyczne, które służą wszystkim krajom UE"15. A w komentarzu Anna Łojewska dodała: „nie oznacza to rezygnacji z samego projektu, który nie podoba się Polsce. Gazprom i jego niemieccy partnerzy mogą sobie poradzić bez kredytów z Europejskiego Banku Inwestycyjnego, choć zapewne zwiększy to koszty"16. Konrad Niklewicz na łamach „Gazety Wyborczej" dodał do tego komentarza słowa premiera Marcinkiewicza: „osiągnęliśmy więcej niż chcieliśmy”. Przyjęty zapis jego zdaniem "gwarantuje, że gazociąg północny nie będzie nigdy współfinansowany $\mathrm{z}$ unijnych pieniędzy"17. Obie gazety opisały to jednak jako wielki triumf polskiego rządu.

Prasa niemiecka pokazała ów szczyt jako przygotowanie Niemiec do objęcia prezydencji w UE w 2007 roku i przedstawiła listę trudnych problemów, z którymi Unia musiała się uporać. W „Der Spiegel” opisano Niemcy jako pośrednika między Wschodem a Zachodem, podnosząc: „w stosunkach z Moskwą Niemcy działały nie jako państwo narodowe, tylko jako siła przewodnia Europy". Magazyn odniósł to także do rurociagu bałtyckiego, który miał być kontynuowany. Co ciekawe, zabrakło zupełnie odniesienia do propozycji, opisywanych przez prasę polską ${ }^{18}$.

\footnotetext{
${ }^{14}$ A. Słojewska: Rozszerzenie z przeszkodami, „Rzeczpospolita”, 13 czerwca 2006.

${ }^{15}$ A. Słojewska: Polska propozycja przyjęta bez oporu, „Rzeczpospolita”, 17 czerwca 2006.

${ }^{16}$ A. Słojewska: Bez pieniędzy na rure, „Rzeczpospolita”, 17 czerwca 2006.

${ }^{17}$ K. Niklewicz: Unia Europejska nie zapłaci za bałtycka rure, "Gazeta Wyborcza", 17-18 czerwca 2006.

${ }^{18}$ R. Beste, R. Neukirch, G. Mascolo, J. Puhl, H.-J. Schlamp, S. Simons: Stärke aus Schwäche, „Der Spiegel” 2006, nr 25.
} 
Tę sytuację można z kolei interpretować jako próbę walki Polaków o zablokowanie inwestycji poprzez instytucje UE. Jak widać, dla Niemców nie miało to większego znaczenia, za to w Polsce zapis przegłosowany na szczycie, mówiący o współfinansowaniu tylko projektów korzystnych dla wszystkich państw Unii, wywołał poczucie wielkiego sukcesu.

W październiku 2006 roku doszło zaś do szczytu UE-Rosja w Lahti. Przed szczytem w „Rzeczpospolitej” spekulowano, iż „Rosja utrzymuje UE jako głównego klienta swoich surowców. [...] Dlatego [...] celem Putina będzie uciszenie innych kontrowersji i dyskusja o energetycznych interesach". Przykładem owego interesu był gaz z olbrzymiego złoża Stockman, który miał płynąć gazociągiem północnym. Kontrowersje dotyczyć zaś miały rosyjskich sankcji wobec Gruzji i niepokojących sygnałów o łamaniu praw człowieka ${ }^{19}$. W "Gazecie Wyborczej” spekulowano: „rozmowy o dostawach gazu i ropy z Rosji są dla Unii tak ważne, że do minimum zostaną zredukowane inne tematy". Europejscy przywódcy mieli znowu naciskać na Rosję, by zapewniła dostęp do swoich złóż gazu, tak by zachodnie koncerny mogły na nich inwestować bez ryzyka. Na łamach „Wyborczej” zastanawiano się, na ile będą oni solidarni, bo tylko to mogło skłonić Rosjan do ustępstw. Przykładem różnic było rozumienie gazociągu północnego: „dla Niemców dywersyfikacją jest właśnie budowa gazociągu północnego przez Bałtyk. Dla Polski to zagrożenie". Zastanawiano się też, czy Putin jechał tam po zwycięstwo ${ }^{20}$. Po szczycie okazało się, że przywódcy podczas spotkania z rosyjskim prezydentem przemówili jednym głosem, na co uwagę zwrócono w „Rzeczpospolitej”, krytykując jego politykę wobec Gruzji i łamanie praw człowieka oraz, co najważniejsze, jednomyślnie wypowiedzieli się na temat konieczności ratyfikowania przez Rosję karty energetycznej. Putin stwierdził zaś: „to prawda, że $45 \%$ gazu importowanego przez Unię pochodzi z Rosji. Ale do UE idzie aż 67\% naszego eksportu gazu. To Rosja jest bardziej zależna od Unii niż Unia od Rosji”21 ${ }^{21}$ W innym artykule w "Rzeczpospolitej” Piotr Zychowicz przedstawił prezydenta

${ }^{19}$ A. Słojewska: UE: głaskać Rosję czy ganić, „Rzeczpospolita”, 18 października 2006.

${ }^{20}$ K. Niklewicz: Rosyjska energia dzieli Unię Europejska, "Gazeta Wyborcza”, 19 października 2006.

${ }^{21}$ A. Słojewska: UE jednym głosem do Putina, „Rzeczpospolita”, 21 października 2006. 
Kaczyńskiego, jako jednego z „pięciu, co uratowali honor Europy”. Polska głowa państwa skrytykowała poczynania w Gruzji i budowę gazociągu północnego ${ }^{22}$. Paweł Świeboda w "Gazecie Wyborczej” dowodził, że przyczyną jedności europejskich przywódców była refleksja, jakiej dokonali po rozlicznych kryzysach i problemach politycznych z udziałem tego kraju. Przekonywał on o strachu Rosjan przed nową polityką energetyczną Europy, mającą na celu stopniowe ograniczanie użycia energii pochodzącej z surowców kopalnych na rzecz energii odnawialnej i zmniejszania zużycia, a "tego właśnie panicznie boi się Rosja”. Kraj ten potrzebował przy tym ogromnych inwestycji europejskich, by móc eksploatować nowe, trudniej dostępne złoża ${ }^{23}$.

Prasa niemiecka także zauważyła omawiany szczyt. „FAZ” pisał o defensywnym nastawieniu europejskich przywódców w jego trakcie. Uzależnienie energetyczne Europy od Rosji rosło znacząco, dlatego „UE musi w przyszłości mówić jednym głosem”, żądał przewodniczący komisji europejskiej Jose Emanuel Barroso. Na łamach dziennika zwracano uwagę na problemy powodujące, że państwom ciężko było mówić jednym głosem, czego przykładem był rurociąg bałtycki. „Napięcia między Niemcami, a Polską wobec gazociągu przez Morze Bałtyckie, który ma zaopatrywać Niemcy z Rosji, nie ułatwiają współpracy" - pisano we frankfurckim dzienniku ${ }^{24}$. O szczycie w Lahti pisała również dziennikarka Kornelia Boelsch w „Süddeutsche Zeitung”, przytaczając ostrzeżenia szefa komisji europejskiej przed upolitycznianiem spraw energii. Kanclerz Merkel popierała przy tym gazociąg północny, dzięki któremu „Niemcy staną się dystrybutorem gazu w Europie. Rurociąg nie ma nikogo wykluczać". Dziennikarka opisała też żądania wobec Rosji ratyfikowania Karty Energetycznej, którą „ratyfikowało już w międzyczasie 47 krajów, w tym Kazachstan”25. W innym komentarzu redaktor zajmujący się sprawami gospodarki Alexander Hagelüken, opisując żądania

${ }^{22}$ P. Zychowicz: O pięciu takich, co uratowali honor Europy, „Rzeczpospolita”, 24 października 2006.

${ }^{23}$ P. Świeboda: Unia wreszcie razem wobec Rosji, "Gazeta Wyborcza”, 23 października 2006.

${ }^{24}$ H. Kafsack: Gegenseitige Abhängigkeit, „Frankfurter Allgemeine Zeitung“, 21 października 2006.

${ }^{25}$ K. Bolesch: EU will mehr Marktwirtschaft, "Süddeutsche Zeitung“, 21 października 2006. 
otwarcia rosyjskiego sektora energetycznego na firmy zachodnie, przytaczał zapewnienia kanclerz Merkel mówiące, że mimo niechęci Rosjan do podpisania dokumentu „Rosja jest pewnym partnerem”. Opisał również chęć Putina do zatarcia złego wrażenia, jaki wywarł kryzys gazowy z Ukrainą na początku 2006 roku $^{26}$.

Szczyt w Lahti był ważnym wydarzeniem i jako takie przedstawiły go gazety w Polsce i w Niemczech. W obu krajach akcentowano, jak istotna była solidarność wśród przywódców europejskich i konieczność mówienia przez UE jednym głosem. Polacy akcentowali przy tym krytykę europejskich przywódców wobec polityki Rosji w Gruzji i brak przestrzegania praw człowieka. Niemcy prawie całkowicie skupili się na sprawach energii. Gazociąg bałtycki został przedstawiony przy tym jako jeden z głównych problemów zakłócających dialog wewnątrz UE.

Oprócz artykułów o UE i gazociągu przy okazji szczytów europejskich Polska prasa odnotowała także różne głosy przy innych okazjach. Tuż przed objęciem prezydencji w UE przez Finlandię w "Rzeczpospolitej” pisano o roli tego kraju w możliwej blokadzie rurociągu bałtyckiego. Mogło okazać się to prawdopodobne dzięki podnoszonym argumentom ekologicznym. Finowie chcieli jednak utrzymać dobre stosunki dwustronne i całej UE ze wschodnim sąsiadem ze względu na intensywną wymianę handlową. „Najkrótsza droga z Brukseli do Moskwy nie wiedzie przez Helsinki, tylko przez Warszawę. Ale może się okazać, że to Finowie, a nie Polacy przekonają Unię do swojej wizji stosunków z Rosją" - podsumowano ${ }^{27}$.

Na łamach "Gazety Wyborczej” odnotowano zaś propozycję Rady Unii Europejskiej uznającą m.in. gazociąg północny za jeden z priorytetowych projektów energetycznych UE. Dzięki temu inwestycja mogła liczyć na wsparcie z pieniędzy unijnych. Podkreślono, że rząd zbagatelizował ten fakt, dodając, iż udało się wprowadzić liczne korzystne dla Polski projekty, mimo tego jednak przedstawił tę propozycję Rady UE jako porażkę polskiego gabinetu, pisząc: „rząd odpuścił bałtycką rurę $^{28}$. Po kilku miesiącach w „Rzeczpospolitej” zauważono jednak

${ }^{26}$ A. Hagelüken: Putin blockt Energiewünsche der EU ab, "Süddeutsche Zeitung“, 23 października 2006.

27 A. Słojewska: Czas na fiński pragmatyzm, „Rzeczpospolita”, 5 lipca 2006.

${ }^{28}$ A. Kublik: Rząd odpuścił bałtycka rurę, "Gazeta Wyborcza”, 26 lipca 2006. 
brak zgody Europejskiego Banku Inwestycyjnego na udzielenie budowniczym rurociągu pożyczki na projekt. Zacytowany został sam prezes banku Philippe Maystadt, mówiący: „nie zgodzę się na to bez akceptacji Polski”. W gazecie podkreślano, że „formalnie Maystadt żadnej zgody Polski nie potrzebuje”, ale "nie zamierza angażować banku w kontrowersyjny projekt" ${ }^{29}$. W innym artykule $\mathrm{w}$ tym dzienniku przytoczono zdanie Janusza Steinhoffa, byłego wicepremiera w rządzie Jerzego Buzka: „wypowiedź prezesa EBI to pozytywny sygnał świadczący o pewnej solidarności z krajami sprzeciwiającymi się projektowi, ale nie będzie mieć wpływu na budowę gazociągu" ${ }^{\prime 30}$.

Przy wyborze nowego prezydenta Estonii, w „Wyborczej” apelowano: „niech Unia pomoże Estonii w sporach z Moskwą”. Toomas Ilves - nowa głowa państwa - zapewnił, że szansę na polepszenie stosunków z Rosją upatrywał w Brukseli, ponieważ był zwolennikiem wspólnej polityki zagranicznej. Prezydent stwierdził przy tym: „brak wspólnej polityki zagranicznej sprawia, że poszczególne państwa UE mogą zawierać umowy, które przynoszą szkodę całej Europie. Najlepszym przykładem jest gazociąg północny" ${ }^{\prime 31}$.

O problemie wspólnej polityki zagranicznej pisano także $\mathrm{w}$ tygodniku „Wprost”. Zdaniem czasopisma na przykładzie rurociągu bałtyckiego można było zaobserwować nie tylko brak wspólnej polityki, ale nawet pomysłu na nią w UE. Zasugerowano wręcz: „,sprawa gazociągu może okazać się detonatorem buntu przeciw dyktatowi wielkich mocarstw »starej Unii«i doprowadzić do głębokiej przebudowy UE. W duchu solidarności, jak mówią liderzy nowych państw UE". W przeciwnym razie kraje te zostałyby popchnięte w kierunku Rosji ${ }^{32}$.

Innym ciekawym głosem była wypowiedź wiceprzewodniczącego Komisji Europejskiej Güntera Verheugena, będąca ostrzeżeniem dla Gazpromu, którą odnotowano w „Rzeczpospolitej”, mówiąca o ko-

${ }^{29}$ A. Słojewska: Europejski Bank Inwestycyjny nie chce finansować gazociagu, „Rzeczpospolita", 9 stycznia 2007. 2007.

${ }^{30}$ A. Słojewska: Europa nie sfinansuje bałtyckiego gazociagu, „Rzeczpospolita”, 9 lutego

${ }^{31}$ Niech Unia pomoże Estonii w sporach z Moskwa, "Gazeta Wyborcza", 25 września 2006.

${ }^{32}$ M. Michaliszyn: Tygrys w rurze, „Wprost” 2005, nr 49. 
nieczności „dostosowania się przez Rosję do przepisów obowiązujących we Wspólnocie", jeśli chciała ona wsparcia UE przy wstąpieniu do WTO i szybkiego podpisania umowy gospodarczej. Unia miała bowiem zamiar wprowadzić „nowe zasady funkcjonowania rynku energii. Spółki nie będą mogły łączyć działalności produkcyjnej i dystrybucyjnej". Do tego Parlament Europejski nakazał Komisji „opracować zasady ograniczenia inwestycji krajów trzecich, które na zasadzie wzajemności nie zgadzają się na umożliwienie dostępu do własnego rynku". Była to reakcja na blokowanie przez Rosję otwarcia swojego rynku dla firm z UE. Przez ową zapowiedź pojawiły się groźby konieczności odsprzedania udziałów Gazpromu w gazociągu północnym. Wywołała ona, jak twierdzi dziennik, wielkie oburzenie wśród władz rosyjskiego koncernu, a jego szef zagroził możliwością wzrostu cen w 2010 roku, jeśli projekt się opóźni, bo „gaz, który ma być nim dostarczany, został już sprzedany" ${ }^{33}$. W „Rzeczpospolitej” odnotowano również zapowiedź Komisji Europejskiej mówiącą o tym, że Bruksela „będzie chronić swoje firmy energetyczne przed inwestorami, którzy kierują się nie tylko chęcią zysku". Sugerowano, iż chodziło tu głównie o rosyjskie koncerny energetyczne. Dodano też: „Unia przejrzała na oczy, dopiero gdy Rosjanie zainteresowali się rynkami jej najważniejszych krajów”. Dalej pisano: „ważne, że nasza walka o zachowanie suwerenności energetycznej znalazła wreszcie zrozumienie ${ }^{\prime 34}$.

Polska prasa widziała rolę Unii Europejskiej w sporze dotyczącym gazociągu północnego $\mathrm{w}$ bardzo wielu aspektach. Pojawiły się wręcz głosy o konflikcie między nowymi a starymi członkami oraz o blokowaniu wspólnego stanowiska UE w dziedzinie energii przez najsilniejsze państwa, czerpiące $\mathrm{z}$ tego największe zyski. Media polskie $\mathrm{z}$ dużą uwagą śledziły też możliwości zablokowania lub finansowania projektu przez Wspólnotę. Z szczególną dozą triumfalizmu pisały o wszelkich decyzjach mających wpływ na utrudnienie budowy.

Z innych ciekawych głosów w prasie niemieckiej o stanowisku Unii Europejskiej wobec gazociągu północnego można wyróżnić artykuły dotyczące wizyty ministra spraw zagranicznych Niemiec Franka Waltera

\footnotetext{
${ }^{33}$ D. Wasilewska: Unia Europejska ostrzega Gazprom, „Rzeczpospolita”, 18 lipca 2007.

${ }^{34}$ Bruksela przejrzała na oczy, "Rzeczpospolita”, 31 sierpnia 2007.
} 
Steinmeiera na Kremlu. W „Süddeutsche Zeitung” pisano o mnożących się problemach Unii z Rosją. Obok nieprzestrzegania praw człowieka, Kosowa, kłótni z Estonią o przeniesienie pomnika armii radzieckiej, wymieniła gazociąg północny, wokół którego „wśród państw położonych nad Morzem Bałtyckim formuje się opór przeciwko budowie"35. Podczas spotkania „minister spraw zagranicznych apelował o europejską orientację gospodarzy". W monachijskim dzienniku przypomniano słowa Putina z 2001 roku o poparciu dla integracji europejskiej, w której pokładał „wielkie nadzieje”, oraz ponownie problemy z zawarciem nowego porozumienia o partnerstwie ${ }^{36}$. Wizyta ta potwierdziła wcześniejsze głosy o tym, iż Niemcy mają grać rolę adwokata Rosji wobec Unii. Minister Steinmeier próbował zachęcić Rosjan do powrotu do dialogu i szukania kompromisu.

W „Süddeutsche Zeitung” opisywano głosy w debacie energetycznej mówiące o szukaniu nowych źródeł energii. Przedstawione zostały propozycje Komisji Europejskiej zmniejszenia uzależnienia od ropy i gazu poprzez zwiększenie wykorzystania odnawialnych źródeł energii oraz ambitne cele: „w roku 2020 Europa powinna zużywać 13\% mniej energii niż dzisiaj i dzięki temu zaoszczędzić nawet 100 miliardów euro kosztów rocznie". Przytoczono także wcześniejsze założenie, by do 2012 roku $12 \%$ produkowanej energii pochodziło ze źródeł odnawialnych, którego nie udało się zrealizować, oraz ogromne koszty planowanego przejścia na ekologiczne surowce ${ }^{37}$.

W dyskusji o stosunku Unii Europejskiej w sprawie gazociągu północnego, gazu i energii najważniejszymi głosami okazały się apele o jedność państw członkowskich w tych sprawach i konieczność podpisania przez Rosję Karty Energetycznej. W tej kwestii prasa w obu krajach była zgodna. Miałoby to bowiem zdaniem dziennikarzy wzmocnić obustronną zależność Europy z Rosją a co za tym idzie - poprawić bezpieczeństwo dostaw czy też wręcz obniżyć ceny. Oprócz tego najważniejszego nurtu pojawiły się także głosy o konflikcie nowych państw Unii ze sta-

\footnotetext{
${ }^{35}$ Komplizierte Beziehungen, „Süddeutsche Zeitung“, 15 maja 2007.

${ }^{36}$ D. Brössel, T. Urban: Steinmeier wirbt um Putin, "Süddeutsche Zeitung“, 16 maja 2007.

${ }^{37}$ A. Hagelüken, J. Rubner: Der Traum von der eigenen Quelle, „Süddeutsche Zeitung", 9 stycznia 2007.
} 
rymi. Na uwagę zasługuje fakt, że prasa polska przy wielu problemach widziała UE jako formę obrony państw środkowoeuropejskich przed Rosją. Publicyści polscy zwracali uwagę na możliwość blokady gazociągu północnego dzięki instytucjom UE. Prasa niemiecka zupełnie się na tym nie skupiała, akcentując potrzebę dialogu i partnerstwa Europy z Kremlem.

\section{Propozycje wspólnej polityki energetycznej}

Oprócz analizowanych powyżej głosów o roli UE w debacie na temat energii na szczególną uwagę zasługuje pomysł wspólnej polityki energetycznej UE.

W „Gazecie Wyborczej” niedługo po kryzysie między Rosją a Ukrainą z początku 2006 roku, który dotknął po części także kraje Unii, pisano o tych wydarzeniach w kategorii szoku, który potrzebny był Europie. Apelowano też: „Unia powinna stworzyć wspólną politykę energetyczną". Proponowano przy tym zasadę trzech muszkieterów „jeden za wszystkich, wszyscy za jednego" - mówiącą o przyjściu z pomocą państwu zagrożonemu odcięciem dostaw. Opisano też inicjatywę polskich europosłów, mającą na celu uniemożliwienie zawierania "takich umów dwustronnych, które byłyby szkodliwe z punktu widzenia pozostałych państw". Jako przykład podano gazociąg północny. Innym ze środków miałoby być połączenie sieci gazowych wszystkich państw, by ewentualna pomoc mogła dojść do skutku. Wprowadzenie tej propozycji w życie nie było jednak łatwe ze względu na opory wewnątrz samej UE ${ }^{38}$. Owe problemy opisano też w „Rzeczpospolitej”, cytując wypowiedź polskiego ministra gospodarki Piotra Woźniaka: „mamy zawieszony w próżni dialog energetyczny UE-Rosja, bo trudno uznać projekt gazociągu północnego za efekt tego dialogu". Zwrócono też uwagę na pełne poparcie Polski dla propozycji wspólnej polityki energetycznej, a wręcz pojawiły się pomysły pójścia dalej i stworzenia Europejskiego Urzędu Energetycznego ${ }^{39}$.

\footnotetext{
${ }^{38}$ K. Miklewicz: Europa madra po szkodzie, „Gazeta Wyborcza”, 17 stycznia 2006.

${ }^{39}$ Dialog energetyczny w próżni, „Rzeczpospolita”, 31 maja 2006.
} 
Na łamach „Gazety Wyborczej” odnotowano zaś „pierwszy w historii Unii projekt »europejskiej polityki energetycznej«", od razu dodając, że „raczej nie spełni on polskich oczekiwań dotyczących energetycznej solidarności". Opisano też przyczyny takiego stanu rzeczy. Komisja proponowała bowiem uwolnienie cen energii oraz zwiększenie udziału źródeł odnawialnych w jej produkcji. Dziennik uznał je za nierealne lub niewystarczające, dodając, iż „,rządy unijnych państw [...] dały do zrozumienia Komisji, że może zaproponować wszystko, pod warunkiem, że nie naruszy »energetycznej suwerenności państw «" ${ }^{40}$.

Za pośrednictwem „Rzeczpospolitej” ambasador RFN Reinhard Schweppe apelował zaś: „pilnie potrzebujemy europejskiej polityki energetycznej". Europa sprowadzała w owym czasie 50\% zużywanej energii, a ta tendencja miała jeszcze wzrosnąć. Dlatego też kraje UE musiały współpracować, szczególnie gdy Rosja zaczynała wykorzystywać surowce jako czynniki polityczne. Do tego przywoływał on unijne propozycje $\mathrm{w}$ sprawach energii, m.in. zmniejszenie zużycia, zwiększenie produkcji ze źródeł odnawialnych czy uwolnienie cen energii i rozdzielenie producentów od dystrybutorów. Przekonywał też, że „sprawujący prezydencję Niemcy pragną intensywnej dyskusji”, a „nowa europejska polityka energetyczna może zrelatywizować w Polsce gwałtowną krytykę niemiecko-rosyjskiego projektu budowy gazociągu północnego", ponieważ wpisywał się on w szerszy kontekst nowych dróg dostaw energii, a i tak był w stanie obsłużyć tylko $25 \%$ dodatkowych potrzeb na gaz. "Chcemy być rzetelnym pośrednikiem zabiegającym o uczciwy i zrównoważony rezultat dla wszystkich 27 państw członkowskich", dodał ambasador ${ }^{41}$.

O solidarności energetycznej pisano również podczas dyskusji o konstytucji europejskiej. W „Rzeczpospolitej” niemiecki korespondent tej gazety Piotr Jendroszczyk przedstawił propozycję Polski w kwestii wpisania zasady solidarności energetycznej do traktatu, co miałoby być kompromisem ze strony Polski wobec ustępstw w systemie głosowania, powodującym obniżenie pozycji Polski. „Solidarność energetyczna na-

\footnotetext{
${ }^{40}$ K. Niklewicz: Unijna energia bez solidarności, „,Gazeta Wyborcza”, 5 stycznia 2007.

${ }^{41}$ R. Schweppe: Pilnie potrzebujemy europejskiej polityki energetycznej, „Rzeczpospolita", 31 stycznia 2007.
} 
leży nam się jak psu zupa" wypowiadał się na ten temat ekscentryczny europoseł Ryszard Czarnecki. Dziennik dodał, że zdaniem polskich dyplomatów byłoby to godne rozpatrzenia, gdyby Niemcy zrezygnowali z budowy gazociagu bałtyckiego, co raczej nie było możliwe ${ }^{42}$.

Prasa polska pisała pozytywnie o wspólnej polityce energetycznej jako o rozwiązaniu korzystnym dla Polski. Nie zapomniano przy tym jednak o trudnościach, jakie towarzyszyły wprowadzaniu tego pomysłu, podnosząc egoistyczne podejście do tego tematu poszczególnych państw. Jako przykład takiego zachowania podano gazociąg bałtycki, godzący $\mathrm{w}$ interesy niektórych członków UE. Wspomnieć też należy o głosie strony niemieckiej w polskich mediach, zachęcającym do dialogu i przekonującym, iż rura bałtycka to część szerszej rozbudowy infrastruktury na skalę europejską.

Prasa niemiecka również odnotowała propozycje wspólnej polityki energetycznej. Na łamach „FAZ” pisano o żądaniach państw Grupy Wyszechradzkiej wprowadzenia polityki energetycznej UE, gdyż były one zależne od Rosji i obawiały się w szczególności rurociągu bałtyckiego. Jak donosił frankfurcki dziennik: „Grupa Wyszechradzka jednak nie przedstawiła konkretnych propozycji żądanej wspólnej polityki energetycznej”. Polscy europosłowie za to proponowali zapis: „umowy dwustronne, które naruszają interesy państw członkowskich UE powinny zostać zabronione" ${ }^{43}$.

W tym samym dzienniku zwrócono uwagę na wezwania przewodniczącego Komisji Europejskiej Jose Barroso: „wszystkie państwa muszą mieć wspólny cel w zabezpieczeniu dostaw energii dla UE”. Komisja proponowała rozbudowę infrastruktury umożliwiającej przekazywanie surowców między członkami wspólnoty, by zapobiec przerwom w dostawach, oraz utworzenie organów kontrolujących rynek energii. Dzięki temu Europa będzie mogła mówić jednym głosem wobec państw dostawców. Barroso zabiegał też o poszukiwanie nowych źródeł energii, pozostawiając $\mathrm{w}$ tej gestii państwom wolną rękę ${ }^{44} \mathrm{~W}$ innym artykule

${ }^{42}$ P. Jendroszczyk: Warszawa zmusza Berlin do ustępstw, „Rzeczpospolita”, 18 maja 2007.

${ }^{43}$ Forderung nach EU-Energiepolitik, "Frankfurter Allgemeine Zeitung“, 18 stycznia 2006.

${ }^{44}$ Brüssel fordert neue Energiepolitik, „Frankfurter Allgemeine Zeitung“, 8 marca 2006. 
przytoczono wypowiedź przewodniczącego: „byłoby nieodpowiedzialnym, robić tak jakby status quo było wystarczające. Energia jest problemem globalnym, który wymaga europejskiej odpowiedzi". Te słowa tłumaczono dużymi oporami państw członkowskich co do pomysłów współpracy energetycznej w $\mathrm{UE}^{45}$.

Na łamach „FAZ” pisano również o zdaniu Angeli Merkel w sprawie proponowanych kompetencji UE w dziedzinie energii. Podczas debaty w Radzie Europejskiej pani kanclerz stwierdziła, iż „,by zwiększyć bezpieczeństwo energetyczne wystarczyłoby poprawić współpracę państw oraz dialog z Rosją i państwami Bliskiego Wschodu". Kanclerz Austrii Wolfgang Schüssel przekonywał jednak, że Europa powinna mówić jednym głosem: „nie może być 25 polityk energetycznych UE. Jednak państwa członkowskie musiałyby same decydować jakich źródeł energii używać". W dyskusjach także inne państwa odnosiły się do tego pomysłu sceptycznie, jednak zgodzono się z tym, że trzeba oszczędzać energię ${ }^{46}$. Po szczycie w „FAZ” informowano o braku woli ze strony państw członkowskich do przekazania kompetencji w zakresie energii na rzecz Brukseli. Przytoczono stanowisko Niemiec, które uznały obecne środki za wystarczające, a solidarność energetyczną oprzeć chciały na Karcie Energetycznej. Polska wystąpiła przy tym jako wielki zwolennik bliższej kooperacji w tych sprawach, który wyraził zdenerwowanie z powodu jej nieuwzględnienia przy budowie gazociągu bałtyckiego. Przewodniczący Komisji Europejskiej poszedł krok dalej, mówiąc, jak podano w dzienniku: „polityka energetyczna mogłaby być motorem integracji”. Mimo wielu sprzeczności Barroso uznał, że „wspólna polityka energetyczna się narodziła, opory są normalne, a za 10 lat UE będzie znacznie dalej" ${ }^{\prime 27}$.

Na łamach „FAZ” w sprawach polityki energetycznej wypowiedział się także Valdas Adamkus, prezydent Litwy. Przekonywał on, jak ważne było ustanowienie wspólnej linii w tej kwestii. Podniósł on potrzebę stworzenia „naprawdę funkcjonującego energetycznego ryn-

\footnotetext{
${ }^{45}$ Barroso fordert engere Energie-Kooperation, "Frankfurter Allgemeine Zeitung", 18 marca 2006.

${ }^{46}$ Merkel gegen neue EU-Kompetenzen, „Frankfurter Allgemeine Zeitung", 24 marca 2006.

${ }^{47}$ H. Kafsack: Ein bißchen mehr Koordination, „Frankfurter Allgemeine Zeitung“, 25 marca 2006.
} 
ku wewnętrznego" i „skoordynowanych działań we współpracy z dostawcami energii". Apelował też o takie prowadzenie polityki, by państwa dostarczające ropę i gaz nie czuły się wykorzystywane, a wręcz podnosił, że trzeba im pomóc w reformach i postępie społecznym. „Jest to konieczne do zbudowania długoterminowych i stabilnych stosunków, dla obustronnych korzyści i dla sformułowania klarownych reguł rynku energetycznego". Prezydent podsumował to wszystko jednym słowem: „solidarność. Na niej opiera się Unia Europejska”. Podkreślał też, że w tej chwili nadszedł czas na podjęcie działań, by „politykę energetyczną UE nie tylko wyrażać jako mglistą teorię, ale przyczynić się do jej urzeczywistnienia" ${ }^{48}$.

Prasa w Niemczech skoncentrowała się na apelach polityków o konieczność stworzenia wspólnej polityki energetycznej. Podkreślano też, jak wielki był opór państw członkowskich, w tym Niemiec. Na dowód tego przytaczano opinie niemieckich polityków. Warto przy tym zaznaczyć, że gazociąg północny prawie się w tym kontekście nie pojawił w komentarzach prasowych.

Na szczególną uwagę zasługuje propozycja polskiego rządu stworzenia energetycznego NATO. W „Rzeczpospolitej” opisywano stanowisko rządu polskiego, który chciał zapisania wspomnianej wcześniej zasady ,jeden za wszystkich, wszyscy za jednego" do zielonej księgi polityki energetycznej UE. Polskie władze poszły krok dalej: „rząd postuluje nawet zmianę traktatów w takim kierunku, aby stworzyć gwarancje dostaw energii na wypadek przerwy w dostawach niezawinionej przez odbiorcę". Chciałby także połączenia systemów krajów członkowskich, by w razie kataklizmów czy przerw w dostawach można było korzystać ze źródeł innego państwa członkowskiego ${ }^{49}$. W innym z komentarzy cytowano prezydenta Lecha Kaczyńskiego, odrzucającego propozycję niemiecką oparcia bezpieczeństwa energetycznego na zasadach OBWE, ponieważ „nie jest to szczególnie żywotna organizacja”. Dalej pisano o stanowisku polskiej głowy państwa, iż: ,jest przekonany, że gwaran-

${ }^{48}$ V. Adamkus: Europa Energiepolitik ist graue Theorie, „Frankfurter Allgemeine Zeitung", 10 października 2007.

${ }^{49}$ A. Słojewska: Polska chce, aby Unia w sprawach energii mówiła jednym głosem, „Rzeczpospolita”, 16 października 2006. 
cją bezpieczeństwa energetycznego państw członkowskich UE oraz USA może być realizacja tzw. energetycznego NATO, którego członkowie zobowiązaliby się do wzajemnej pomocy i działań w razie zakłóceń w dostawach nośników energii z Rosji i innych regionów”. Przytoczono też stanowisko Niemiec, mówiące o tym, że „polski projekt wykluczający udział Rosji ma zbyt konfrontacyjny charakter. Poza tym miałyby w nim uczestniczyć USA, postrzegane w Berlinie bardziej jako konkurent niż partner na rynkach energetycznych" ${ }^{\prime 50}$.

Prasa niemiecka także wspomniała o tym pomyśle. Na łamach „FAZ” pisano o polskiej propozycji energetycznego NATO jako reakcji na kryzys gazowy z Ukrainą. Plan miał na celu wytworzenie wspólnych rezerw gazu i wzajemnego wsparcia w razie odcięcia od dostaw. Dziennik opisywał to jako wyraz i rezultat strachu Polaków przed możliwością szantażu ze strony Rosji. Dodał też: „inny aspekt tego zamiaru wywodzi się z obaw przed planowanym niemiecko-rosyjskim gazociagiem przez Morze Bałtyckie". Polska zaproponowała, by wspólnie decydować o budowaniu nowych rurociągów czy też połączeń między istniejącymi. Plany miały również objąć państwa spoza UE, jak Ukrainę czy Mołdawię, a nawet Gruzję. Dziennik zwrócił uwagę na pomysł stworzenia struktur niezależnych od UE ${ }^{51}$. W innym artykule na łamach „FAZ” podniesiono, że w polskiej propozycji „Rosja byłaby zatem z tego definitywnie wykluczona". Na to nie chciały się zgodzić Niemcy, ponieważ ten kraj był dla nich już od dziesięcioleci godnym zaufania partnerem w dostawach energii. Krytykowano też pomysł włączenia do paktu USA, ponieważ „z punktu widzenia polityki energetycznej, Ameryka z europejskiej perspektywy od dawna uważana jest za konkurenta, a nie jedynie za partnera w interesach". Odnotowano, że „w proces uzyskiwania bezpieczeństwa energetycznego musieliby zostać włączeni wszyscy, zachodnie państwa konsumujące, tak samo jak państwa tranzytowe i producenci”, a „UE musi móc wejść na rynek jako zjednoczenie odbiorców, by przejąć siłę na rynku od producentów”. W „FAZ” przekonywano przy tym, że jest możliwa do osiągnięcia sytuacja między dostawcami

\footnotetext{
${ }^{50}$ P. Jendroszczyk: Dobry poczatek z historia w tle, „Rzeczpospolita”, 9 marca 2006.

${ }^{51}$ Polen schlägt "Energie-NATO vor", „Frankfurter Allgemeine Zeitung“, 26 stycznia 2006.
} 
a producentami, w której każdy wygrywa ${ }^{52}$. W tygodniku „Der Spiegel" opisano zaś opory niemieckiego ministra spraw zagranicznych przed tym rozwiązaniem ze względu na potrzebę zredukowania roli energii jako narzędzia politycznego. Twierdził przy tym: „trzeba, chcąc nie chcąc, szukać porozumienia z dostawcami". Jako szansę na odprężenie sytuacji widział on stworzenie rozwiązania na wzór KBWE, która „doprowadziła strony zimnej wojny do jednego stołu" ${ }^{53}$.

Prasa w obu krajach dostrzegła propozycję energetycznego NATO. Polska prasa odniosła się do niej przychylnie, za to niemieccy dziennikarze skrytykowali ja podobnie jak rząd w Berlinie, uważając za zbyt konfrontacyjną. Stanowiska, jakie zajmowały media w obu krajach, najlepiej obrazuje porównanie do NATO i KBWE, przytaczane w dyskusji. Polska proponowała rozwiązanie bardziej radykalne, w szczególności wobec Rosji, czując zagrożenie ze strony tego państwa, Niemcy zaś widzieli w tej kwestii kompromis między wszystkimi stronami zaangażowanymi w handel energia.

Media po obu stronach Odry zwróciły uwagę na problem wspólnej polityki energetycznej państw europejskich. Zgodnie uznały, że ma on duże znaczenie, a dyskusja i kompromis w tym obszarze są nadzwyczaj ważne dla wszystkich. Warto zaznaczyć, że w Polsce doszukiwano się przy tej okazji związków z budową gazociągu bałtyckiego, a raczej chęcią jej przerwania przez rząd polski, niejednokrotnie opisując wspólną politykę energetyczną jako środek ku temu. W Niemczech ten aspekt został w dużym stopniu pominięty.

\section{Podsumowanie}

Prasa w Polsce i w Niemczech szeroko komentowała sprawę gazociagu północnego $\mathrm{w}$ analizowanym okresie od października 2005 do października 2007. Projekt ten wywołał duże kontrowersje i miał kluczowy wpływ na stosunki między Polską a Niemcami. Odbiło się to również na komentarzach prasowych po obu stronach Odry.

${ }^{52}$ J. Leithäuser: Entgegengesetzte Richtungen, „Frankfurter Allgemeine Zeitung“, 8 marca 2006.

${ }^{53}$ R. Beste: »Kalter Krieg“, „Der Spiegel“ 2006, nr 9. 
Istotną rolę w sprawie budowy gazociagu odegrała Unia Europejska. Głównym punktem dyskutowanym i opisywanym w prasie okazała się Europejska Karta Energetyczna, której Rosja nie chciała ratyfikować. Dokument ten miał sprawić, by koncerny europejskie mogły zyskać dostęp do rosyjskiego rynku gazu, co uważano zarówno w Polsce, jak i w Niemczech za jeden ze środków służących do poprawienia bezpieczeństwa energetycznego Europy. Innym rozważanym problemem okazała się jedność państw - członków UE w sprawach energii, której uzyskanie nie było łatwe. Gazociąg północny jako projekt interpretowany był różnorako. Polska prasa postrzegała instytucje unijne jako kolejną możliwość do storpedowania projektu. Niemieckie media przedstawiały gazociąg jako część europejskiego systemu, mogącego poprawić bezpieczeństwo energetyczne na kontynencie.

Te same wydarzenia komentowane były w podobny sposób, np. szczyt Rosja-UE w Soczi, gdzie Rosja nie zgodziła się na podpisanie karty energetycznej, a gazociąg miał być środkiem dla niej do umocnienia się na rynkach europejskich. Spotkać się można też było z różnymi interpretacjami, jak podczas szczytów UE w Brukseli i Rosja-UE w Lahti, podczas których polska prasa skupiła się na krytyce Rosji i możliwościach zablokowania inwestycji, a prasa w Niemczech na kwestiach energetycznych czy na budowaniu porozumienia z Rosją.

W ramach Unii pojawił się też pomysł wspólnej polityki energetycznej, wobec której nie było jedności wśród członków UE. Polska prasa pisała o wysuniętym przez polski rząd postulacie zasady trzech muszkieterów „jeden za wszystkich, wszyscy za jednego", mającej objawiać się tym, iż w razie przerwania dostaw dla jednego członka, inni dostarczaliby surowce ze swoich rezerw. Chciano to także wpisać do nowej europejskiej konstytucji. Polska prasa zinterpretowała to jako formę zabezpieczenia przed zagrożeniami, które mógł nieść za sobą gazociąg północny. Niemieckie media odniosły się do tych pomysłów z dystansem, cytując swoich polityków, mówiących o tym, iż obecne środki są wystarczające. W tej debacie polski rząd poszedł o krok dalej i zaproponował projekt stworzenia energetycznego NATO, opierającego się na zasadach Paktu Północnoatlantyckiego, mającego włączyć do współpracy także USA, co poparły media nad Wisłą. Pomysł ten nie znalazł 
jednak uznania u polityków i $\mathrm{w}$ mediach niemieckich. Potraktowany został jako wyraz strachu Polski przed szantażem ze strony Rosji. W Niemczech lansowano koncepcję współpracy energetycznej na zasadach OBWE, uznając koncepcję podobną do NATO, jako zbyt konfrontacyjną względem Rosji. Przekonywano też, że USA są konkurentem w pozyskiwaniu źródeł energii, a nie partnerem.

W kwestii roli UE $\mathrm{w}$ budowie gazociągu północnego panowała w polskiej prasie szczególna zgodność opinii. $\mathrm{W}$ tonie radykalnym wypowiadano się jedynie w tygodniku „Wprost”, jednak prezentowane $\mathrm{w}$ nim poglądy nie różniły się od prezentowanych w pozostałych analizowanych gazetach. Tłumaczyć to można przekonaniem, że dzięki UE uda się zablokować gazociąg. Także w Niemczech prasa przedstawiająca różne punkty widzenia pisała o roli UE w tym projekcie w podobnym tonie, przedstawiając go w europejskiej perspektywie.

\section{Abstract \\ The European Union's role in the Baltic Pipeline controversy. Comments in the Polish and German press}

The Baltic Pipeline turned out to be a controversial undertaking from the start of its implementation. The main role in this was played by the media, which bestowed publicity on the problem and, in particular, on the apprehensions provoked by this project.

A very important role in this matter was performed by the European Union. It happened thus because practically all the states involved in the controversy were members and, as such, referred to its institutions in attempting to block the project. The EU's role also had its second layer. Throughout, the parties involved in building the pipeline emphasised the European character of the project, which was to serve all the member states.

This article aims at describing the debate in the press which was held in Poland and in Germany and at presenting what was written about the role of the European Union in the dispute around the Baltic Pipeline and in what context.

The main issue described in the press turned out to be the European Energy Charter, which Russia was unwilling to ratify. This document was to provide the European energy companies with access to the Russian gas market, which was regarded, both in Poland and in Germany, as one of the measures helping to improve Europe's energy security. Another issue under consideration turned out to 
be the unity of the EU member countries as far as energy is concerned; something which was not easy to obtain. The Baltic Pipeline as a project was not interpreted uniformly. The Polish press perceived in the EU institutions an opportunity to torpedo it. The German media presented the pipeline as part of a European system, capable of improving the energy security for the entire continent.

An idea of a common energy policy also emerged in the EU; it was not, however, faced with unity among its members. The Polish press referred to a Three Musketeers' one for all, all for one principle, which was to be implemented by the UE' states' supplying raw materials from their reserve stocks in a case of the interruption of supplies to one of the members. The German media, however, were cool toward the idea. The Polish government went a step further in this debate and suggested the formation of an energy NATO, to include the US into their co-operation as well. This suggestion was not appreciated, however, among German politicians and the media. The latter promoted a concept of energy co-operation along the OSCE lines and deemed a NATO-like approach as too confrontational toward Russia. 